\section{<RESPONSE >}

\section{脊椎炎の急性期診断のpitfall}

私の書きました論文（脊椎炎に対する治療strategy） に対して貴重なご意見いただき，大変興味深く読まさせ ていただきました。この疾患の問題点をしっかりと捉え られ，診断，治療に対する先生の真摰な態度が伝わり， 先生には敬服いたします。初診時の診断率をいかに上げ るか??その為に脳神経外科医に何ができるか?というご 意見ですが，この点に関して私は全く異論はありません. 私は, 先生がご指摘のように超急性期診断の難しさを痛 感していますし，また多くが脳神経外科を受診する前に 他科を受診しているにもかかわらず，それでも見落とさ れることが多いのが現状です。

私は静岡県立総合病院脳神経外科で花北順哉先生のも と, 多くの脊椎脊髄疾患を約 2 年半にわたり勉強させて いただきました，膨大な症例を抱える施設で, 花北先生 のもと多くのことを経験できたことは，これまでの脳神 経外科医としてのキャリアの中でも大変貴重なもので す。私は平成13年 4 月より東京女子医科大学脳神経セン タ一脳神経外科に戻り脊鹃専門外来を開き, 現在, 新た に脊髄外科部門の立ち上げに努力しています。現在, 最 も痛感しますのは, 今まで多くの脳神経外科医があまり

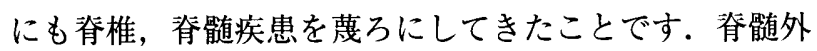
科の看板さえ上げれば患者が集まるものではなく, 地道 な外来診療や啓蒙活動なしには症例は集まりません．こ の雑誌を読まれている会員の方々にはいないだろうと思 いますが, 現実として脳神経外科医の中には, “頚椎は 診るけど, 胸腰椎は診ない”, “腫瘍や A V M は脳外科の 患者で，その他は整形外科”等の認識を持っている医師 が残念ながら非常に多いです。拉そらくそのような脳外 科医は脊椎炎など診断できないのではなく，“みもしな い”のではないでしょうか。一方，整形外科に扔いても 脊椎を専門にしていない先生も多く，例え過去に整形外 科を受診したことがあり, 異常がなかったと診断されて いても，よく調べると異常がみつかることも多く経験し ます．事例をだすときりがないので省略しますが，脊椎 炎の早期診断率を上げるには “患者の訴えを真摰に聞く こと”，“患者をよく診ること”，“整形外科を信用しない こと（すばらしい整形外科医は多くいます，その点は誤 解のないように)”が重要であると考えます。また神経 学的所見を伴わない超急性期の脊椎炎などは多くが back pain等で疑われます。しかしback painの患者を外
来でどれだけの脳神経外科医がきちんと診察しているか は疑問です，特殊なことではなく，当たり前にback painを脳神経外科疾患の症候として捉える啓蒙が必要と 思われます．脊椎炎の急性期診断は見逃されることが多 いですが，画像診断やbiopsyをやるかどうかといった技 術的な問題以前の問題がpitfallではないかと思います。

横道にそれますが，椎間板へルニアや宜柱管狭窄症な どの脊椎変性疾患は脳神経外科の手術対象となる脳疾患 に比へ，その人口比率は圧倒的に多くいます. 欧米の脳 神経外科の現状を見るまでもなく，これらの手術対象患 者をみすみす見逃していることは日本の脳神経外科の将 来を暗くすることになるでしょう。医療保険や医療施設 体系の再整備, 専門医の増加など社会的見地からみまし ても，21世紀，日本脳神経外科の発展のためには脊椎脊 䯣の外科の発展が必要不可欠と考えます。

尚, 今回このような形で私の論文に対する手紙の返信 を書く機会を与えてくださった中川 洋編集委員長に感 謝いたします。

2001年（平成13年）11月 2 日

東京女子医科大学脳神経センター

脳神経外科塩川和彦 